\title{
Menilai Dampak Evaluasi Produk konsumen dan Kepercayaan Pada Niat Pembelian Kembali Pada Lingkungan E-Commerce
}

\author{
Dwi Indah Pratiwi ${ }^{1}$ \\ Fakultas Ekonomi dan Bisnis \\ Universitas Airlangga, Indonesia. \\ Email: dipratiwi75@gmail.com
}

\begin{abstract}
ABSTRAK
Penelitian ini bertujuan untuk menganalisis faktor-faktor yang mempengaruhi niat pembelian kembali pada e-commerce.Metode penelitian ini menggunakan metode kuantitatif deskriptif dengan penyebaran kuesioner sebagai metode perolehan data. Teknik analisis data menggunakan regresi linier berganda. Data diperoleh 96 responden yang berasal dari berbagai kalangan responden indonesia melalui kuisioner berbasis web. Hasil penelitian menunjukan bahwa persepsikepercayaan, persepsi manfaat, persepsi harga kompetitor, memiliki hubungan yang signifikan dan positif terhadap niat pemembelian kembali di $e$ commerce.Sedangkan persepsirisikotidak memiliki hubungan signifikan terhadap niat untuk pemembelian kembali.
\end{abstract}

Kata Kunci : $\quad$ E-commerce; Niat pembelian kembali; Persepsi Konsumen.

\section{Assessing the Impact of Consumer Product Evaluation and Trust on Repurchase Intention in the E-Commerce environment}

\begin{abstract}
This study aims to analyze the factors that influence repurchase intentions in e-commerce. This research method uses quantitative descriptive method by distributing questionnaires as a method of data acquisition. The data analysis technique uses multiple linear regression. Data were obtained by 96 respondents from various Indonesian respondents through a web-based questionnaire. The results showed that the perceived trust, perceived usefulness, perceived competitive prices, had a significant and positive relationship with the intention to buy back in e-commerce.While perceived risk does not have a significant relationship with repurchase intention.
\end{abstract}

Keywords : $\quad$ E-commerce; Repurchase Intention; Perceived Consumer.

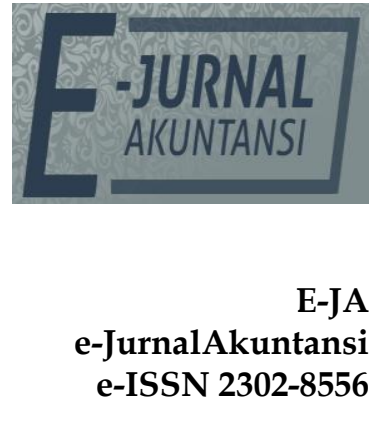

Vol. 29 No. 2

Denpasar, November

2019

Hal. 522-534

Artikel masuk: 06 Juni 2019

Tanggal diterima: 31 Oktober 2019 


\section{PENDAHULUAN}

Dengan adanya internet ribuan jaringan komputer dapat saling terhubung baik secara individual hingga organisasi di seluruh dunia (Laudon, 2016). Terdapat beberapa keunggulan mengapa internet sangat diminati banyak orang, yaitu dengan konektivitas dan jangkauan yang luas internet dapat mengurangi biaya yang harus dikeluarkan seperti biaya komunikasi, transaksi dan juga internet dapat mendistribusikan informasi dan pengetahuan secara cepat (Laudon, 2016). Dalam aktivitas transaksi bisnis penggunaan internet dikenal dengan istilah Electronic Commerce (e-commerce) (McLeod dan Schell, 2004).

Seperti yang telah kita ketahui bahwa penggunaan internet meningkat dengan pesat, hal ini menjadikan perhatian bagi para pemilik usaha yang menjalankan bisnisnya untuk memasarkan produk melalui atau melibatkan internet sebagai pemanfaatanya. Dalam hal ini keterlibatan pelanggan dalam pembelian via online menjadi suatu hal yang penting (Wijaya dan Jasfar, 2014). Karaketistik utama dari e-commerce menurut Indrajit (2001) yaitu terjadinya transaksi jual beli, jasa dan informasi antar kedua pihak dengan internet sebagai media utama dalam penghubung proses transaksi tersebut. Biasanya, transaksi $e-$ commerce dapat terjadi antara sesama organisasi bisnis (B2B) atau antara organisasi bisnis dengan konsumen (B2C) (Corbitt et al., 2003), (Indrajit, 2001), (Laudon, 2016) (McLeod dan Schell, 2004).Situs web e-commerce bukan hanya alat untuk mendukung transaksi bisnis, tetapi juga saluran perusahaan untuk berinteraksi dan berkomunikasi dengan konsumen mereka (Al-Natour et al., 2011).

Adanya kasus penipuan dalam transaksi online, membuat kepercayaan dari pembeli online menjadi berkurang atau bahkan tidak percaya lagi untuk berbelanja via online. Hal ini di dukung oleh penelitian dari Awad dan Ragowsky (2008) yang menyatakan bahwa kurangnya kepercayaan cenderung mencegah konsumen membeli secara online dan menyebabkan mereka mengabaikan keranjang belanja mereka selama transaksi online.

Kepercayaan dan risiko merupakan duafaktor penting yang mempengaruhi perilaku konsumen di lingkungan online dan offline dimana keduanya diukur berdasarkan persepsi individu (Azam dan Qiang, 2011). Kepercayaan merupakan sebuah hubungan timbal balik dimana penjual dan pembeli harus saling mempercayai agar pertukaran transaksi efektif dapat terjadi (Hawes et al., 1989). Dengan tingkat kepercayaan yang tinggi pada penjual, tekanan yang berkaitan pada risiko yang dirasakan pembeli akan tinggi untuk teradinya transaksi dimana pembeli lebih cenderung memusatkan pembelian dengan mitra penukar di mana tingkat risiko yang dirasakan baik secara pribadi (Hawes et al., 1989). Kepercayaan dalam lingkungan e-commerce bersifat imperative karena konsumen online umumnya lebih rentan terhadap risiko transaksi, terutama ketika ketidakpastian mengenai kualitas produk atau layanan yang ditawarkan oleh penjual online hadir (Ba dan Pavlou, 2002). Salah satu cara yang paling sering untuk mengurangi risiko ini adalah dengan menciptakan nilai untuk meningkatkan kepercayaan antara penjual online dan pembeli (Zeithaml, 1988). Dengan demikian, karena tuntutan konsumen dari perubahan bisnis secara bersamaan, kepercayaan dapat menjadi alat untuk menciptakan pendapatan dan pertumbuhan jangka panjang. 
Beberapa penelitian sebelumnya telah membahas mengenai niat pembelian kembali seperti (Pappas et al., 2014) yang menyatakan persepsi pelanggan memainkan peran penting dalam meningkatkan keputusan pembelian mereka. Zhang et al., (2011) menunjukkan bahwa kualitas hubungan online dan persepsi kegunaan situs web berdampak positif terhadap niat pembelian kembali pelanggan.Temuan (Shin, 2013)menunjukkan bahwa kualitas situs dapat menjadi faktor penting untuk meningkatkan niat pembelian kembali dari perspektif pelanggan. Selain itu penelitian yang dilakukan Ou et al., (2014) menunjukan konsep guanxi dan persepsi kepercayaan dapat memprediksi niat pembelian kembali pembeli.Penelitian ini mencoba mengisi gap beberapa literatur sebelumnya dalam kesediaan konsumen untuk membeli kembali pasca pembelian terhadap situs online shopping dalam membeli suatu produk dengan model berbeda yang dilihat dari persepsi kepercayaan, persepsi risiko, persepsi manfaat, dan persepsi harga kompetitif.

Theory of Planned Behavior (TPB) pada tahun 1985 muncul setelah Theory of Reasoned Action pada tahun 1980 yang dicetuskan oleh Ajzen (1985) dipakai untuk memahami niat tindakan individu pada waktu dan tempat tertentu. Dalam teori ini dijelaskan bahwa setiap individu mampu untuk mengontrol diri. Faktor utamanya adalah niat tindakan dipengaruhi oleh sikap mengenai kemungkinan bahwa semua tindakan akan memiliki hasil yang diharapkan dan evaluasi subjektif risiko dan manfaat dari hasil itu. Pencapaian perilaku tergantung pada motivasi dan kemampuan untuk mengontrol tindakan(Ajzen, 1985).

Kepercayaan terhadap e-commerce sangat dibutuhkan oleh pembeli online, karena itu juga dapat mempengaruhi baik buruknya online shopping tersebut. Kepercayaan dalam e-commerce dapat dipahami dalam dua tahap yang berbeda: pra-pembelian dan pasca-pembelian (Kim dan Benbasat, 2009) (Zhang et al., 2011). Di dalam penelitian ini, kepercayaan diukur melalui pasca pembelian. Dimana dengan adanya pasca pembelian, kita dapat mengetahui apakah pembeli akan berniat untuk membeli kembali di situs online shopping yang sama atau tidak, apakah pembeli online merasa puas terhadap barang yang sudah dibelinya. Pada tahap pasca-pembelian, konsumen memiliki pengalaman langsung yang substansial dan mereka langsung membuat keputusan apakah mereka akan melakukan tindakan untuk membeli kembali dengan penjual yang sama (Kim dan Benbasat, 2009). Pelanggan harus merasa aman dan aman jika mereka berbelanja online, sementara itu adalah kewajiban penjual untuk mengembangkan dan mempertahankan kepercayaan pelanggan (Palvia, 2009). Dalam pembelian ulang, konsumen cenderung mengevaluasi suatu produk atau layanan berdasarkan kinerja sebenarnya dari produk atau layanan yang dirasakan setelah konsumsi. Menurut Liao dan Keng (2013)terlepas dari pengalaman pelanggan, kepercayaan dan kepuasan perlu dipertahankan dalam belanja online karena mereka adalah faktor penting dari retensi pelanggan ketika menghadapi situasi negatif seperti kegagalan layanan. Gefen et al., (2008) berpendapat bahwa kepercayaan merupakan hal yang penting bagi semua pelanggan tidak terpengaruh pada tingkat pengalaman mereka. Namun kepuasan pelanggan dan niat pembelian kembali akan lebih besar ketika pengalaman lebih rendah daripada ketika pengalaman tinggi. Perilaku 
pengambilan risiko, seperti keputusan pembelian kembali adalah fungsi kepercayaan dan persepsi risiko kontekstual dari perilaku jika tingkat kepercayaan melebihi ambang risiko yang dirasakan, maka konsumen cenderung terlibat dalam perilaku pembelian ulang (Fang et al., 2014).

$\mathrm{H}_{1}$ : Persepsi kepercayaan berhubungan signifikan terhadap niat pembelian kembali.

TAM adalah perpanjangan teoritis dari TRA yang menjelaskan penentu perilaku sadar. TAM memberikan dasar teori yang berpengaruh dan kuat untuk menjelaskan motif pengguna terhadap penggunaan teknologi (Weerasinghe \& Hindagolla, 2018) . TAM berpendapat bahwa penggunaan teknologi aktual dibentuk oleh niat perilaku yang pada gilirannya dipengaruhi oleh Perceived Ease of Use dan Perceived Usefulness. Perceived Usefulnessmerupakan sejauh mana seseorang percaya bahwa menggunakan sistem tertentu akan meningkatkan kinerja pekerjaannya (Weerasinghe \& Hindagolla, 2018). Pada era sekarang, semuanya sudah dilakukan dengan serba online. Banyak orang yang menginginkan semuanya serba cepat dan praktis. Kini kegunaan dari sistem transaksi berbasis online ini sudah dapat diterima dan dipercaya oleh masyarakat. Kepercayaan online telah dianggap sebagai penentu utama dari kegunaan yang dirasakan, terutama dalam lingkungan online (Gefen et al., 2003) (Pavlou, 2003). Manfaat dari situs web tergantung pada efektivitas teknologi yang relevan dan sejauh mana layanan manusia di belakang teknologi (Gefen et al., 2003). Kegunaan dari situs online shopping ini sangat mempermudah bagi konsumen yang ingin membeli suatu produk secara praktis, melalui ini mereka dapat mengetahui segala informasi tentang produk secara online, apakah mereka mendapatkan barang yag sesuai, dan apakah dengan melakukan pembelian secara online dapat meningkatkan pengalaman pembelian mereka. Davis (1989) menyatakan bahwa individu membentuk niat perilaku terhadap belanja online sebagian besar didasarkan pada penilaian kognitif tentang bagaimana hal itu akan meningkatkan kinerja belanja mereka. Har Lee et al., (2011) mengatakan bahwa manfaat yang diterima pelanggan merupakan sampai sejauh mana konsumen yakin apabila belanja online dapat meningkatkan kinerja transaksinya.

$\mathrm{H}_{2}$ : Persepsi Manfaat berhubungan signifikan terhadap niat pembelian kembali.

Risiko yang dirasakan oleh konsumen dalam online shopping merupakan peran penting dalam pasca pembelian. Dinev dan Hart (2006) menyatakan bahwa persepsi risiko dapat didefinisikan sebagai adanya ketidakpastian yang dirasakan pihak konsumen yang disebabkan oleh perilaku penjual online shopping yang dapat mengakibatkan kerugian bagi konsumen. Dalam konteks $e-$ commerce, risiko yang dirasakan dapat digambarkan sebagai sejauh mana konsumen percaya bahwa menggunakan situs web mungkin memiliki konsekuensi negatif atau hasil yang tidak diinginkan (Glover dan Benbasat, 2010).Setiap adanya risiko yang dirasakan oleh konsumen itu akan dapat mengurangi hubungan baik yang menyangkut mengenai kepercayaan antara konsumen dan penjual online yang mengakibatkan konsumen tersebut tidak mau membeli lagi di situs online shopping yang sama (Crespo \& Del Bosque, 2010). Salah satu cara untuk mempertahankan konsumen ini adalah dengan cara mempertahankan kepercayaan mereka di toko online tersebu, jika konsumen 
sudah percaya pada situs online shopping tersebut maka ada intensitas untuk membeli kembali produk di situs online shopping yang sama (Gefen dkk., 2003; Jarvenpaa, Tractinsky, dan Vitale, 2000; Pavlou, 2003).

$\mathrm{H}_{3}$ : Persepsi risiko berhubungan signifikan terhadap niat pembelian kembali.

Harga merupakan faktor penting bagi kesediaan konsumen untuk membeli lagi di situs online shopping yang sama. Chen dan Dubinsky (2003) mengatakan bahwa pembeli online cenderung melihat harga sebagai komponen biaya yang penting dan membandingkan harga antara alternatif yang berbeda. Dalam lingkungan online, kualitas produk cenderung dapat dibandingkan di seluruh vendor dan konsumen umumnya akrab dengan informasi produk (Kim dkk., 2012). Biasanya konsumen akan mengumpulkan tentang informasi harga dari suatu produk yang akan dibelinya dari situs online shopping yang berbeda. Hal ini sejalan dengan penelitian Choudhury dan Karahanna (2008) yang mengatakan bahwa konsumen dapat menggunakan banyak situs web untuk mengumpulkan informasi dan membandingkan harga produk. Konsumen biasanya akan lebih tertarik pada situs online shopping yang menawarkan rentang harga yang dapat diterima oleh konsumen.

$\mathrm{H}_{4}$ : Persepsi kompetitif harga berhubungan signifikan terhadap niat pembelian kembali.

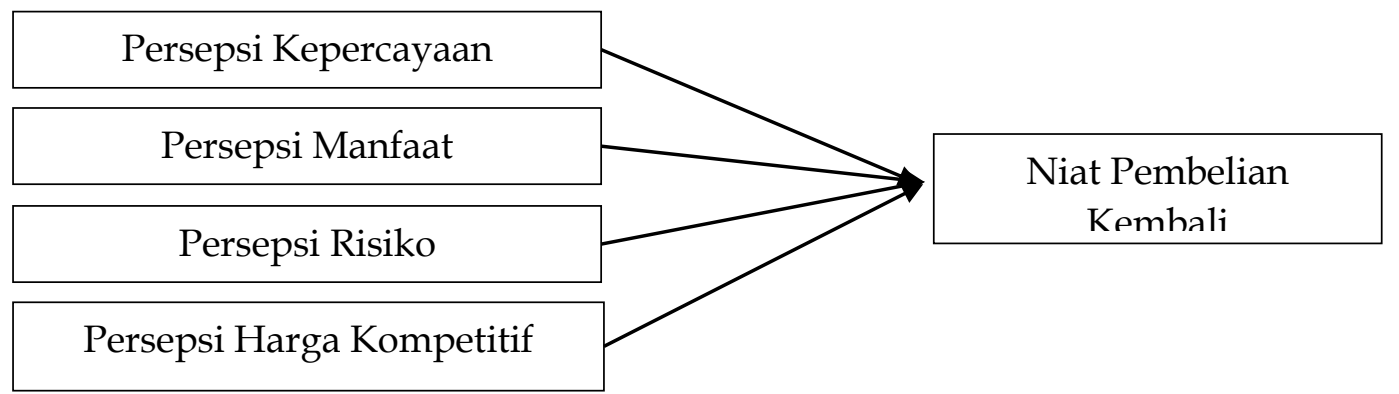

\section{Gambar 1. Model Penelitian}

Sumber: Data Penelitian, 2019

\section{METODE PENELITIAN}

Penelitian ini menggunakan pendekatan kuantitatif deskriptif. Menurut Sugiyono (2014) pendekatan penjelasan bertujuan untuk mendapatkan kausalitas antar variabel melalui pengujian hipotesis. Dalam penelitian ini menggunakan penelitian survei, karena mengumpulkan semua informan dari beberapa responden menggunakan kuesioner yang nantinya akan diolah data. Dalam penelitian ini dirancang satu set kuesioner yang mengadopsi teknik sampling klaster Cochran (1977) dan mendistribusikannya ke responden melalui kuisioner berbasis internet. Individu diminta untuk menunjukkan persepsi mereka mengenai pentingnya setiap item berdasarkan skala likert lima poin 1-5, dengan 1 penilaian poin terendah "sangat tidak setuju" hingga 5 penilaian poin tertinggi "sangat setuju".Pada pertanyaan kuesioner dibagi menjadi 2 bagian, bagian pertama dirancang untuk mengumpulkan informasi demografi responden seperti jenis kelamin, umur, status pekerjaan, e-commerce yang sering dikunjungi, benda apa yang dibeli di e-commerce. Bagian ke dua responden diminta untuk menjawab beberapa pertanyaan mengenai faktor-faktor yang mempengaruhi 
niat pembelian kembali seperti persepsi kepercayaan, persepsi manfaat, persepsi risiko dan persepsi harga kompetitif.

Penelitian ini menggunakan populasi pengguna e-commerceyang belokasi di Kota Surabaya. Sampel data yang berhasil diperoleh 96 responden. Metode analisis data yang digunakan menggunakan uji analisis regresi berganda menggunakan perangkat lunak SPSS 25. Variabel dependen dari penelitian ini niat pembelian kembali. Sedangkan variabel independenya diantaranya persepsi kepercayaan, persepsi manfaat, persepsi risiko, persepsi harga kompetitif.

\section{HASIL DAN PEMBAHASAN}

Sebanyak 97 kuisoner yang dapat digunakan dikumpulkan dari berbagai kalangan responden indonesia melalui kuisioner berbasis web. Sebagian besar pria lebih banyak meluangkan waktunya untuk melakukan belanja online daripada wanita terlihat $58,3 \%$ pembelian online dilakukan oleh pria dengan rentang usia terbanyak yaitu sebesar $64,9 \%$ pada usia $21-26$ tahun yang tentunya pada usia tersebut kebanyakan dari responden adalah yang sudah bekerja terlihat dari angka prosentasi yang sudah bekerja 63,9\% pernah melakukan pembelian online. E-commerce yang sering dikunjungi oleh responden yaitu yang pertama Shopee sebesar 51,5\% kedua lazada sebesar 15,5\% dan ketiga adalah bukalapak dan tokopedia sebesar $12,4 \%$. Barang yang paling dicari adalah fashion sebesar $38,1 \%$.

\section{Tabel 1. Demografi Responden}

\begin{tabular}{|c|c|c|c|}
\hline Kategori & Frekuensi & Persen & Kumulatif \\
\hline \multicolumn{4}{|l|}{ Jenis Kelamin } \\
\hline Pria & 24 & 24,7 & 24,7 \\
\hline Wanita & 73 & 75,3 & 100,0 \\
\hline \multicolumn{4}{|l|}{ Umur } \\
\hline $15-20$ & 22 & 22,7 & 81,4 \\
\hline $21-26$ & 63 & 64,9 & 59,8 \\
\hline$<26$ & 12 & 12,4 & 100 \\
\hline \multicolumn{4}{|l|}{ Status } \\
\hline Sudah berkerja & 62 & 63,9 & 63,9 \\
\hline Mahasiswa & 19 & 19,6 & 83,5 \\
\hline Pelajar & 16 & 16,5 & 100 \\
\hline \multicolumn{4}{|l|}{ E-commerce } \\
\hline Blibli & 1 & 1,0 & 1,0 \\
\hline Bukalapak & 12 & 12,4 & 13,4 \\
\hline Lazada & 15 & 15,5 & 28,9 \\
\hline OLX & 5 & 5,2 & 34,0 \\
\hline Shopee & 50 & 51,5 & 85,6 \\
\hline Tokopedia & 12 & 12,4 & 97,9 \\
\hline Zalora & 2 & 2,1 & 100 \\
\hline \multicolumn{4}{|l|}{ Tipe Pembelian } \\
\hline Book & 4 & 4,1 & 4,1 \\
\hline Fashion & 37 & 38,1 & 42,3 \\
\hline Make up & 18 & 18,6 & 93,8 \\
\hline Computer tools & 4 & 4,1 & 97,9 \\
\hline
\end{tabular}




\begin{tabular}{lrrrr}
\hline & Kategori & Frekuensi & Persen & Kumulatif \\
\hline Souvenir & 2 & 2,1 & 100 \\
Lainya & 32 & 33,0 & 75,3 \\
\hline
\end{tabular}

Sumber: Data Penelitian, 2019

Tahap pertama yang dilakukan adalah uji reliabilitas untuk memastikan apakah kuesioner yang disusun baik untuk mengukur gejala dan menghasilkan data valid. Hasil analisis reliabilitas untuk seluruh indikator pengukuran variabel yang ditunjukkan dari nilai Cronbach's Alphaprespsi kepercayaan 0,801, untuk persepsi manfaat 0,820, untuk Persepsirisiko 0,728, persepsiharga kompetitif 0,820 dan untuk niat pembelian kembali sebesar 0,647 .

Dapat dikatakan bahwa seluruh indikator pengukuran variabel telah lolos uji reliabilitas karena nilai cronbach's alpha lebih dari 0,6. Maka dapat disimpulkan bawha konstruk pada setiap indikator variabel dapat dikatakan valid dan reliabel.

Tabel 2.Hasil Pengujian Reliabilitas

\begin{tabular}{lccc}
\hline \multicolumn{1}{c}{ Konstruk Variabel } & N & Cronbach's Alpha & Keterangan \\
\hline Persepsi Kepercayaan & 4 & .801 & Reliabel \\
Persepsi Manfaat & 2 & .820 & Reliabel \\
Persepsi Risiko & 2 & .728 & Reliabel \\
Persepsi Harga kompetitif & 3 & .820 & Reliabel \\
Niat pembelian kembali & 3 & .647 & Reliabel
\end{tabular}

Sumber: Data Penelitian, 2019

Tahap kedua adalah pengujian multikolinearitasuntuk mengidentifikasi adanya permasalahan asumsi klasik yaitu multikolineratitas antar variabel. Nilai hasil pengujian menunjukan bahwa nilai tolerance untuk semua variabel lebih besar dari 0,1. Sementara nilai VIF untuk semua variabel kurang dari 10. Maka dapat disimpulkan bahwa data yang digunakan tidak terjadi gejela multikolineritas.

Tabel 3. Hasil pengujian Multikolineritas

\begin{tabular}{|c|c|c|c|c|c|c|c|}
\hline \multirow[t]{2}{*}{ Model } & \multicolumn{2}{|c|}{$\begin{array}{l}\text { Unstandardized } \\
\text { Coefficients }\end{array}$} & \multirow{2}{*}{$\begin{array}{c}\begin{array}{c}\text { Standardized } \\
\text { Coefficients }\end{array} \\
\text { Beta }\end{array}$} & \multirow[t]{2}{*}{$\mathrm{t}$} & \multirow[t]{2}{*}{ Sig. } & \multicolumn{2}{|c|}{$\begin{array}{l}\text { Collinearity } \\
\text { Statistics }\end{array}$} \\
\hline & B & $\begin{array}{l}\text { Std. } \\
\text { Error }\end{array}$ & & & & Tolerance & VIF \\
\hline (Constant) & 0,926 & 0,379 & & 2,442 & 0,018 & & \\
\hline $\begin{array}{l}\text { Persepsi harga } \\
\text { kompetitif }\end{array}$ & 0,351 & 0,12 & 0,383 & 2,927 & 0,005 & 0,41 & 2,438 \\
\hline $\begin{array}{l}\text { Persepsi } \\
\text { kepercayaan }\end{array}$ & 0,044 & 0,112 & 0,05 & 0,395 & 0,694 & 0,439 & 2,279 \\
\hline $\begin{array}{l}\text { Persepsi } \\
\text { manfaat }\end{array}$ & 0,558 & 0,138 & 0,554 & 4,037 & 0 & 0,373 & 2,684 \\
\hline Persepsi risiko & $-0,189$ & 0,135 & $-0,177$ & $-1,394$ & 0,169 & 0,434 & 2,303 \\
\hline
\end{tabular}

a Dependent Variable: NIAT PEMBELIAN KEMBALI

Sumber: Data Penelitian, 2019

Uji ANOVA digunakan menentukan apakah model penelitian yang digunakan sudah layak uji. Hasil uji ANOVA menunjukkan model yang digunakan layak untuk diuji dilihat dari tingkat signifikansi 0.000 dengan taraf signifikansi 5\%.Koefisien Determinasi $\left(R^{2}\right)$ bertujuan untuk menguji tingkat keeratan atau keterikatan antara variabel dependen dan variabel independen 
yang bisa dilihat dari besarnya nilai adjusted R-square (Ghozali, 2013). Berdasarkan hasil estimasi model regresi, diperoleh adjusted $\mathrm{R}^{2}$ sebesar 0.553 (55 $\%$ ). Hasil estimasi tersebut menujukkan bahwa variasi dalam variabel dependen niat untuk membeli kembali dapat dijelaskan sebesar $55 \%$ oleh variasi dalam variabel independen yaitu kepercayaan, manfaat barang yang dibeli, risiko, persaingan harga dan sisanya sebesar $0.45 \%$ dijelaskan oleh variabel lain di luar model.Untukmenguji bagaimana pengaruh variabel independen secara individual terhadap variabel dependennya maka digunakan uji $\mathrm{T}$.

Tabel 4. Hasil Regresi Berganda

\begin{tabular}{|c|c|c|c|c|c|}
\hline \multirow{2}{*}{ Model } & \multicolumn{2}{|c|}{$\begin{array}{l}\text { Unstandardized } \\
\text { Coefficients }\end{array}$} & \multirow{2}{*}{$\begin{array}{c}\begin{array}{c}\text { Standardized } \\
\text { Coefficients }\end{array} \\
\text { Beta }\end{array}$} & \multirow[b]{2}{*}{$\mathrm{t}$} & \multirow[b]{2}{*}{ Sig. } \\
\hline & B & $\begin{array}{c}\text { Std. } \\
\text { Error }\end{array}$ & & & \\
\hline (Constant) & 0,085 & 0,401 & & 0,211 & 834 \\
\hline Persepsi kepercayaan & 0,376 & 0,109 & 0,313 & 3,440 & 001 \\
\hline Persepsi manfaat & 0,400 & 0,090 & 0,404 & 4,429 & ,000 \\
\hline Persepsi risiko & $-0,005$ & 0,050 & $-0,007$ & $-0,092$ & ,927 \\
\hline Persepsi harga kompetitif & 0,184 & 0,090 & 0,168 & 2,052 & ,043 \\
\hline Adjusted R Square & \multicolumn{2}{|c|}{0,534} & & & \\
\hline $\mathrm{F}$ & \multicolumn{2}{|c|}{21.871} & & & \\
\hline Sig. & \multicolumn{2}{|c|}{$.000^{\mathrm{b}}$} & & & \\
\hline
\end{tabular}

a. Dependent Variable: NIAT PEMBELIAN KEMBALI

Sumber: Data Penelitian, 2019

Bedasarkan hasil pengujian hipotesis 1 memilikinilai signifikasi dari kepercayaan lebih kecil dari $a=5 \%(0,001<0,05)$ yang artinya persepsi kepercayaan berpengaruh signifikan terhadap niat pembelian kembali pada situs jual beli (ecomerce) tertentu. Maka dapat disimpulkan bahwa hipotesis 1 diterima. Nilai koefisien regresi dari variabel presepnsi kepercayaan 0,376 dan ditandai sebagai hubungan positif. Hal in berarti jika ada peningkatan persepsi kepercayaan sebesar 0,376 maka akan mengarah kepada peningkatan niat pembelian kembali.Bedasarkan teori perilaku yang direncakan (TPB) hal ini memberikan bukti bahwa penilaian konsumen terhadap kemampuan untuk melakukan peluang pembelian online dan kontrol perilaku yang dirasakan untuk terlibat dalam pembelian online akan memengaruhi niat untuk membeli serta secara langsung memengaruhi perilaku pembelian itu sendiri(Azam dan Qiang, 2011). Menurut hasil survey yang didilakukan memberi dukungan empiris bahwa pasar e-commercememenuhi persyaratan pelanggan dan membuat mereka puas akan meningkatkan kepercayaan mereka untuk membeli di pasar e-commerce dengan demikian mengarahkan pada pembelian kembali.Hasil ini sejalan dengan beberapa penelitian yang telah dilakukanseperti (Shiau \& Luo, 2012; Teo dkk., 2008)yang menunjukanbahwa kepercayaan adalah faktor kunci yang menentukanmendorong kepuasan pelanggan yang pada akhirnya membuat niat pembelian kembali. Selain itu juga pada penelitianFang dkk (2014)menegaskan bahwa terdapat hubungan positif antara kepercayaan serta hubungan antara kepercayaan dan niat pembelian kembali.Menurut (Gefen dkk., 2003), konsumen e-commerce secara umum akan menghindari pembelian dari e-commerceyang tidak meyakinkan dan tidak 
mereka percayai, atau mereka menganggap bahwa e-commerce tersebut berperilaku yang dapat membuat kepercayaan untuk membeli menjadi buruk.

Bedasarkan hasil pengujian hipotesis 2 memiliki nilai signifikasi lebih kecil dari $\alpha=5 \%(0,000<0,05)$ yang artinya persepsi manfaat berpengaruh signifikan terhadap niat pembelian kembali pada situs jual beli e-commerce tertentu.Maka dapat disimpulkan bahwa hipotesis 2 diterima. Nilai koefisien regresi dari variabel presepnsi manfaat 0,400 dan ditandai sebagai hubungan positif. Hal in berarti jika ada peningkatan persepsi manfaat sebesar 0,400 maka akan mengarah kepada peningkatan niat pembelian kembali.Menuruthasil pengamatan yang dilakukan, mayoritas responden setuju bahwa penyelesaikan pembelian produk dengan cara yang efisien akan lebih mungkin untuk menunjukkan niat membeli kembali yang lebih kuat. Dengan demikian, dapat dilihat bahwa konsumen yang mendapatkan manfaat dan penggunaan positif dari pembelian produk atau jasa cenderung melakukan pembelian kembali di masa depan.Hal ini sejalan dengan penelitian yang dilakukanWen dkk (2011) yang menunjukan hasil bahwa variabel persepsi manfaat secara signifikan berpengaruh positif terhadap online repurchase intention.Selain itu dalam penelitianElla $\mathrm{dkk}(2012)$ mengatakan bahwa para pelanggan akan merasakanmanfaat ketika mereka mendapatkan kemudahan untuk bertransaksi yang akan meningkatkan kepuasan mereka yang pada akhirnya meningkatkan niat mereka untuk membeli kembali.

Bedasarkan hasil pengujian hipotesis 3 memiliki nilai signifikasi dari variabel persepsirisiko lebih besar dari $\alpha=5 \%(0,927>0,05)$ yang artinya persepsirisiko tidak berpengaruh signifikan terhadap niat pembelian kembali pada situs jual beli (ecomerce) tertentu.Makadapat disimpulkan bahwa hipotesis 3 ditolak. Menurut hasil pengamatan yang dilakukan, mayoritas responden merasa bahwa mereka mampu memiliah situs website mana yang dapat meyakinkan mereka untuk membeli dan mana yang berusaha untuk menipu. Selain itu mereka juga dapat melihat review atau komentar para pembeli yang sudah melakukan pembelian pada situs atau e-commerce tersebut yang nantinya menjadi pertimbangan untuk membeli produk secara online jadi risiko yang diterima tidak akan berpengaruh terhadap pembelian mereka. Untuk hasil ini tidak sejalan dengan penelitianCrespo dan Del Bosque (2010) bahwa persepsirisiko berhubungan positif terahadap niat untuk membeli kembali.Namun terdapat penelitian yang sependapat dengan hasil ini yaituKim dan Benbasat (2009) yang menunjukan hasil persepsi risiko tidak berpengaruh terhadap niat pembelian kembali melalui $e$-commerce, banyak orang memunculkan ketidakpastian apabila mereka melakukan transaksi melalui e-commerce.

Bedasarkan hasil pengujian hipotesis 4 memiliki nilai signifikasi lebih kecildari $\alpha=5 \%(0,043<0,05)$ yang artinya persepsi harga komepetitif berpengaruh signifikan terhadap niat pembelian kembali pada situs jual beli (ecomerce) tertentu.Maka dapat disimpulkan bahwa hipotesis 4 diterima Nilai koefisien regresi dari variabel persepsi harga kompetitif 0,184 dan ditandai sebagai hubungan positif. Hal in berarti jika ada peningkatan persepsi harga kompetitif sebesar 0,184 maka akan mengarah kepada peningkatan niat pembelian kembali.Menurut hasil pengamatan yang dilakukan, mayoritas responden berpendapat bahwa kualitas produk yang ditawarkan sesuai dengan harga yang dibebankan, ketika harga yang tawarkan oleh produsen masuk akal 
bagi konsumen maka secara keseluruhan konsumen akan puas dengan harga produk dan akan mempertimbangkan informasi tentang harga produk yang akan dibeli(Chib, 2012). Hasil penelitian ini mendukungpenelitian Garbarino dan Maxwell, (2010) Xia dan Monroe, (2010) yang mengatakan bahwa adanya keadilan harga menunjukkan pengaruh positif dari persepsi harga terhadap niat pembelian kembali.Persepsi harga merupakan suatu strategi penjualan maupun promosi yang mempengaruhi kepuasan pelanggan dan niat pembelian kembali terhadap belanja online (Ha et al., 2010). Ketika seseorang berbelanja di internet, konsumen tidak dapatbenar-benar melihat produk tersebut mereka tidak yakin bahwa apa yang diwakili di web konsisten dengan apa yang sebenarnya diterima. Dalam kondisi yang ditandai dengan ketidakpastian kinerja seperti itu, persepsi harga cenderung memainkan peran peningkatan dalam menentukan baik kepuasan pasca pembelian dan niat untuk kembali (Liu dan Arnett, 2000).

\section{SIMPULAN}

Hasil empiris pada penelitian ini menemukan bahwa umumnya pria dapat meluangkan waktu lebih banyak dari wanita dalam membeli produk secara online dan produk yang banyak dibeli adalah produk fashion. Persepsi Kepercayaan, Persepsi manfaat, dan persepsi harga kompetitif memiliki hubungan signifikan dan kuat terhadap niat pembelian kembali di e-commerce yang artinya dengan adanya persepsi kepercayaan, persepsi manfaat dan persepsi harga kompetitif antar e-commerce dapat mendorong niat seseorang untuk membeli kembali pada e-commerce yang mereka tuju.

Namun tidak untuk persepsi akan risiko yang didapat dalam melakukan transaksi pembelian hal ini menunjukan bahwa responden telah memiliki pengalaman dalam melakukan transaksi online. Mereka mampu memiliah situs website mana yang dapat meyakinkan mereka untuk membeli dan mana yang berusaha untuk menipu. Selain itu mereka juga dapat melihat review atau komentar para pembeli yang sudah melakukan pembelian pada situs atau $e-$ commerce tersebut yang nantinya menjadi pertimbangan untuk membeli produk secara online. Oleh karena itu persepsi risiko tidak terlalu mempengaruhi niat seseorang untuk membeli kembali. Dalam penelitian ini terdapat sejumlah keterbatsan, pertama responden dalam penelitian ini sebagian besar terdiri dari seseorang yang dewasa dan telah bekerja dimana hal untuk penggunaan $e$ commerce telah terbiasa dan kurang mewakili penggunaan ecomerce di usia remaja dimana kaum milenial sekarang sudah dapat bertransaksi dengan $e$ commerce. Penelitian mendatang disarankan untuk menggunakan sampel yang lebih bervariasi dengan mencari responden remaja supaya padangan akan niat pembelian dengan e-commerce lebih tergeneralisir. Kedua pada penelitian ini hanya menggunakan 4 variabel untuk melihat pengaruh terhadap niat pembelian kembali diharapkan untuk menambahkan variasi faktor-faktor yang dapat digunakan untuk melihat pengaruh terserbut. 


\section{REFERENSI}

Ajzen, I. (1985). From intentions to actions: A theory of planned behavior. In Action control (pp. 11-39). Springer.

Al-Natour, S., Benbasat, I., \& Cenfetelli, R. (2011). The adoption of online shopping assistants: perceived similarity as an antecedent to evaluative beliefs. Journal of the Association for Information Systems, 12(5), 347.

Awad, N. F., \& Ragowsky, A. (2008). Establishing trust in electronic commerce through online word of mouth: An examination across genders. Journal of Management Information Systems, 24(4), 101-121.

Azam, A., \& Qiang, F. (2011). Theory of planned behavior, economic value, trust and perceived risk in e-commerce: an integrated model. In 5th Annual International Conference on Business and Society in a Global Economy, Athens, Greece (pp. 19-22).

Ba, S., \& Pavlou, P. A. (2002). Evidence of the effect of trust building technology in electronic markets: Price premiums and buyer behavior. MIS Quarterly, 243-268.

Chen, Z., \& Dubinsky, A. J. (2003). A conceptual model of perceived customer value in e- commerce: A preliminary investigation. Psychology $\mathcal{E}$ Marketing, 20(4), 323-347.

Chib, S. S. (2012). Empirical study pertaining to the effect of price on customer satisfaction with respect to Dominos and Pizza HUT. International Journal of Applied Services Marketing Perspectives, 1(2), 131.

Choudhury, V., \& Karahanna, E. (2008). The relative advantage of electronic channels: a multidimensional view. MIS Quarterly, 179-200.

Cochran, W. G. (1977). Sampling techniques-3.

Corbitt, B. J., Thanasankit, T., \& Yi, H. (2003). Trust and e-commerce: a study of consumer perceptions. Electronic Commerce Research and Applications, 2(3), 203-215.

Crespo, A. H., \& Del Bosque, I. R. (2010). The influence of the commercial features of the Internet on the adoption of e-commerce by consumers. Electronic Commerce Research and Applications, 9(6), 562-575.

Davis, F. D. (1989). Perceived usefulness, perceived ease of use, and user acceptance of information technology. MIS Quarterly, 319-340.

Dinev, T., \& Hart, P. (2006). An extended privacy calculus model for e-commerce transactions. Information Systems Research, 17(1), 61-80.

Ella, T., Agus, S., \& Untrung, K. (2012). Analisis faktor-faktor kunci dari niat pembelian kembali secara online (study kasus pada konsumen Fesh Shop). Jurnal Bisnis Dan Ekonomi, 19(2).

Fang, Y., Qureshi, I., Sun, H., McCole, P., Ramsey, E., \& Lim, K. H. (2014). Trust, satisfaction, and online repurchase intention: The moderating role of perceived effectiveness of e-commerce institutional mechanisms. Mis Quarterly, 38(2).

Garbarino, E., \& Maxwell, S. (2010). Consumer response to norm-breaking pricing events in e-commerce. Journal of Business Research, 63(9-10), 1066-1072.

Gefen, D., Benbasat, I., \& Pavlou, P. (2008). A research agenda for trust in online environments. Journal of Management Information Systems, 24(4), 275-286. 
Gefen, D., Karahanna, E., \& Straub, D. W. (2003). Trust and TAM in online shopping: an integrated model. MIS Quarterly, 27(1), 51-90.

Ghozali, I. (2013). Aplikasi Analisis Multivariate dengan Program IBM SPSS 23. Semarang: Badan Penerbit Universitas Diponegoro.

Glover, S., \& Benbasat, I. (2010). A comprehensive model of perceived risk of $e-$ commerce transactions. International Journal of Electronic Commerce, 15(2), 4778.

Ha, H.-Y., Janda, S., \& Muthaly, S. K. (2010). A new understanding of satisfaction model in e-re-purchase situation. European Journal of Marketing, 44(7/8), 9971016.

Har Lee, C., Cyril Eze, U., \& Oly Ndubisi, N. (2011). Analyzing key determinants of online repurchase intentions. Asia Pacific Journal of Marketing and Logistics, 23(2), 200-221.

Hawes, J. M., Mast, K. E., \& Swan, J. E. (1989). Trust earning perceptions of sellers and buyers. Journal of Personal Selling \& Sales Management, 9(1), 1-8.

Indrajit, R. E. (2001). E-commerce: Kiat dan strategi bisnis di dunia maya. Jakarta: PT. Elex Media Komputindo.

Jarvenpaa, S. L., Tractinsky, N., \& Vitale, M. (2000). Consumer trust in an Internet store. Information Technology and Management, 1(1-2), 45-71.

Kim, D., \& Benbasat, I. (2009). Trust-assuring arguments in B2C e-commerce: impact of content, source, and price on trust. Journal of Management Information Systems, 26(3), 175-206.

Kim, H.-W., Xu, Y., \& Gupta, S. (2012). Which is more important in Internet shopping, perceived price or trust? Electronic Commerce Research and Applications, 11(3), 241-252.

Laudon, K. C., \& Laudon, J. P. (2016). Management information system. Pearson Education India.

Liao, T.-H., \& Keng, C.-J. (2013). Online shopping delivery delay: Finding a psychological recovery strategy by online consumer experiences. Computers in Human Behavior, 29(4), 1849-1861.

Liu, C., \& Arnett, K. P. (2000). Exploring the factors associated with Web site success in the context of electronic commerce. Information $\mathcal{E}$ Management, $38(1), 23-33$.

McLeod, R., \& Schell, G. (2004). Sistem informasi manajemen. Indeks.

O. Pappas, I., G. Pateli, A., N. Giannakos, M., \& Chrissikopoulos, V. (2014). Moderating effects of online shopping experience on customer satisfaction and repurchase intentions. International Journal of Retail $\mathcal{E}$ Distribution Management, 42(3), 187-204.

Ou, C. X., Pavlou, P. A., \& Davison, R. (2014). Swift guanxi in online marketplaces: The role of computer-mediated communication technologies. MIS Quarterly, 38(1), 209-230.

Palvia, P. (2009). The role of trust in e-commerce relational exchange: A unified model. Information \& Management, 46(4), 213-220.

Pavlou, P. A. (2003). Consumer acceptance of electronic commerce: Integrating trust and risk with the technology acceptance model. International Journal of Electronic Commerce, 7(3), 101-134. 
Shiau, W.-L., \& Luo, M. M. (2012). Factors affecting online group buying intention and satisfaction: A social exchange theory perspective. Computers in Human Behavior, 28(6), 2431-2444.

Shin, J. I., Chung, K. H., Oh, J. S., \& Lee, C. W. (2013). The effect of site quality on repurchase intention in Internet shopping through mediating variables: The case of university students in South Korea. International Journal of Information Management, 33(3), 453-463.

Sugiyono, P. D. (2014). Populasi dan sampel. Metode Penelitian Kuantitatif, Kualitatif Dan RED, 291, 292.

Teo, T. S. H., Srivastava, S. C., \& Jiang, L. (2008). Trust and electronic government success: An empirical study. Journal of Management Information Systems, 25(3), 99-132.

Weerasinghe, S., \& Hindagolla, M. C. B. (2018). Technology acceptance model and social network sites (SNS): a selected review of literature. Global Knowledge, Memory and Communication, 67(3), 142-153.

Wen, C., Prybutok, V. R., \& Xu, C. (2011). An integrated model for customer online repurchase intention. Journal of Computer Information Systems, 52(1), 14-23.

Wijaya, M., \& Jasfar, F. (2014). Pengaruh rancangan situs, harga, kepercayaan dan keamanan terhadap pembelian produk fashion melalui online shopping. Jurnal Manajemen Dan Pemasaran Jasa, 7(2), 31-62.

Xia, L., \& Monroe, K. B. (2010). Is a good deal always fair? Examining the concepts of transaction value and price fairness. Journal of Economic Psychology, 31(6), 884-894.

Zeithaml, V. A. (1988). Consumer perceptions of price, quality, and value: a means-end model and synthesis of evidence. Journal of Marketing, 52(3), 222.

Zhang, Y., Fang, Y., Wei, K.-K., Ramsey, E., McCole, P., \& Chen, H. (2011). Repurchase intention in $\mathrm{B} 2 \mathrm{C}$ e-commerce $-\mathrm{A}$ relationship quality perspective. Information $\mathcal{E}$ Management, 48(6), 192-200. 